\title{
Research Concerning the Correlations Between Urinary Tract Infections and Congenital Malformations of the Renourinary System
}

\author{
Moréh Zsuzsanna, Voicu Lucia Sanda \\ Department of Pediatry 2, University of Medicine and Pharmacy, Tîrgu Mureș, Romania
}

\begin{abstract}
Introduction: Congenital malformations of the urinary system are risk factors for the development of urinary tract infections (UTI). Besides the severity of the malformation, urinary infection is always associated with poor prognosis for these patients. Late discovery of the malformation background, after several urinary tract infection episodes, contributes to the development of chronic pyelonephritis that may lead to chronic renal failure.

Material and method: The study involved patients with renal and urinary tract congenital malformations treated at the Pediatric Nephrology Department from Tîrgu Mureș over a period of 6 years, who associated urinary tract infection.

Results: Out of the total of 432 patients with congenital malformations of the urinary system, 270 had had at least one or several episode(s) of urinary tract infections in their medical history. Vesico-ureteral reflux and obstructive lesions of the urinary tract were most frequently associated with urinary infections. During the time when no ultrasound screening had been performed, the malformation background was usually diagnosed at the time of the first urinary infection episodes.

Conclusions: The incidence of urinary tract infections in patients with renal and urinary tract congenital malformations depends on the type of the underlying malformation, and the time of diagnosis of the malformation background. Prevention of irreversible complications requires early diagnosis of the urinary system malformations that can be performed through ultrasound screening in the neonatal period.
\end{abstract}

Keywords: urinary tract infection, ultrasound screening, renal and urinary tract congenital malformations

Received: 24 January 2013

\section{Introduction}

Urinary tract infections are the third cause of localized infections in children (after respiratory and digestive infections). Congenital malformations of the urinary system and especially obstructive ones are essential contributing factors in the development of urinary tract infections in children $[1,2,3]$.

A study performed by Muntean I. on 323 patients with urinary tract infection showed that the risk of developing urinary tract infections is 4.53 times as high, and the risk of developing recurrent urinary tract infections is 3.4 times as high in case of patients with renourinary malformations than in patients without malformation background [4].

Other studies showed that the incidence of renourinary malformations in children with urinary tract infection is $40-50 \%$. According to certain authors, vesico-ureteral reflux is the most frequent anomaly occurring in patients with urinary tract infection; it is demonstrated in about $30 \%$ of the patients $[5,6]$. The late diagnosis of the malformation background worsens the prognosis of these patients.

The main objectives of this study are: establishing the incidence of urinary tract infection in patients with congenital malformations of the urinary system based on sex, age, type of malformation, time of diagnosis of the malfor-

Correspondence to: Zsuzsanna Moréh

E-mail: morehzsuzsanna@gmail.com mation background, and emphasizing the importance of early diagnosis of congenital renourinary malformations, before complications occur.

\section{Material and methods}

Studying the cases of the Pediatric Nephrology Compartment from Tîrgu Mureș during an interval of 6 years (between 2003 and 2008) we selected the patients diagnosed with congenital malformations of the urinary system. We noted the following:

- presence or absence of urinary tract infections or recurrent urinary tract infection episodes in the personal medical history;

- incidence of urinary tract infections based on sex, age group, the patient's environment and type of congenital malformation of the urinary system;

- time of diagnosis of the renourinary congenital malformation - by ultrasound screening or during targeted examinations prompted by occurrence of the first complications.

\section{Results}

Out of the total of 432 patients with congenital malformations of the urinary system, admitted between 2003 and 2008 to the Pediatrics Clinic No. 2 from Tîrgu Mureș, the majority $(62.5 \%)$ have had one or several episode(s) of urinary tract infections in their personal medical history (Table I). 
Table I. Distribution of patients with congenital malformations of the urinary system, who presented one or several episodes of urinary tract infection

\begin{tabular}{lcc}
\hline UTI & Frequency & $\%$ \\
\hline Absent & 162 & 37.5 \\
Present & 111 & 25.7 \\
Recurrent & 159 & 36.8 \\
Total & 432 & 100.0 \\
\hline
\end{tabular}

After studying the incidence of urinary tract infection according to sex and age of the patients of the study group, we noted an increased incidence in males of the newborn and infant age groups, while the urinary tract infection incidence is obviously increased in females in children over 1 year (Table II).

Considering the distribution of patients according to their environments we noted that patients with congenital malformations of the urinary system coming from urban areas have been diagnosed more frequently with urinary tract infections and recurrent urinary tract infections (Figure 1).

Analyzing the patient group with urinary infection in the medical history according to the underlying renourinary malformation, we noted that vesico-ureteral reflux and obstructive uropathies are most frequently related to urinary infections (Figure 2).

During neonatal ultrasound screening of congenital renourinary malformations performed between January 2006 and December 2009 at the Pediatric Clinic No. 2 from Tîrgu Mureș, 76 cases of congenital anomalies of the urinary system have been identified.

Comparing the data of the 3 years period (2006-2008) when neonatal ultrasound screening of congenital malformations of the urinary system has been performed with data of 3 years period (2003-2005) when this screening has not been performed, we noted a higher frequency of urinary tract infection and recurrent urinary tract infection episodes in the years between 2003 and 2005 (Figure 3).

Studying separately the patient group with urinary tract malformations diagnosed by ultrasound screening, who also had urinary tract infection, we obtained the following data: 15 (26.7\%) of the 56 patients followed-up for a longer time had urinary infection, which emphasizes again

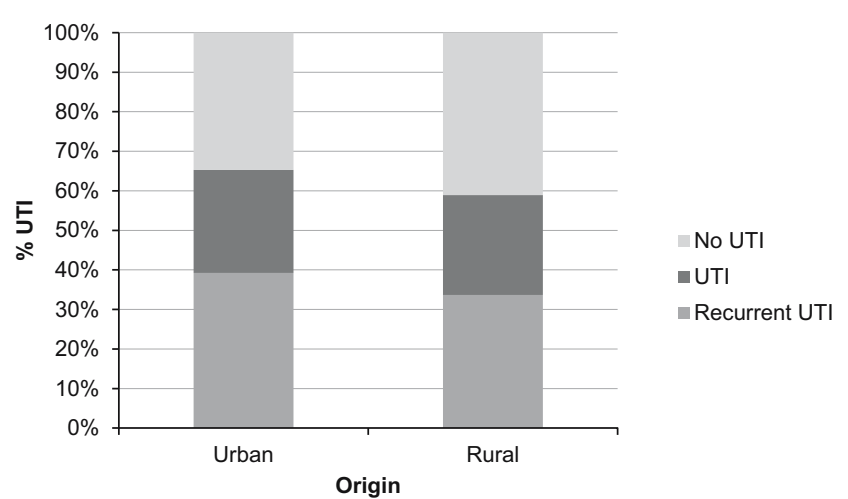

Fig. 1. Graphical representation of the percentage of patients who developed urinary tract infections according to the area of origin

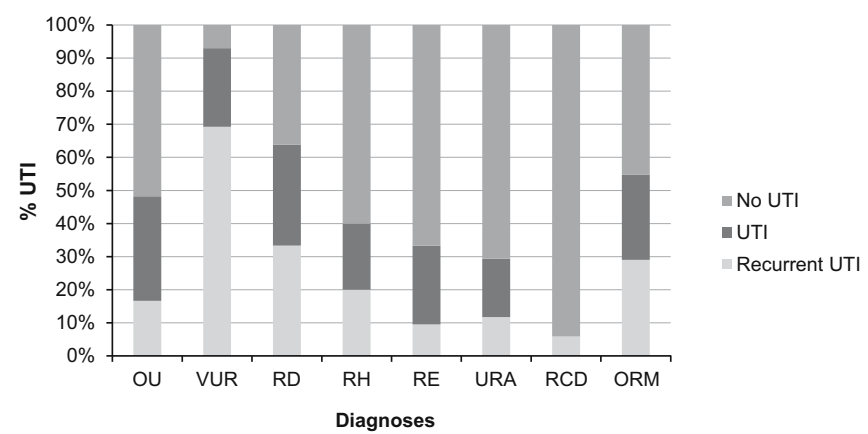

Fig. 2. Graphical representation of patients who presented one or several episodes of urinary tract infections according to type of subsequent congenital renourinary tract malformation

$\mathrm{OU}=$ obstructive uropathy, $\mathrm{VUR}=$ vesicouretheral reflux, $\mathrm{RD}=$ renal duplication, $\mathrm{RH}=$ renal hypoplasia, RE = renal ectopia, URA = unilateral renal agenesis, RCD = renal cystic disease, ORM = other renal malformations

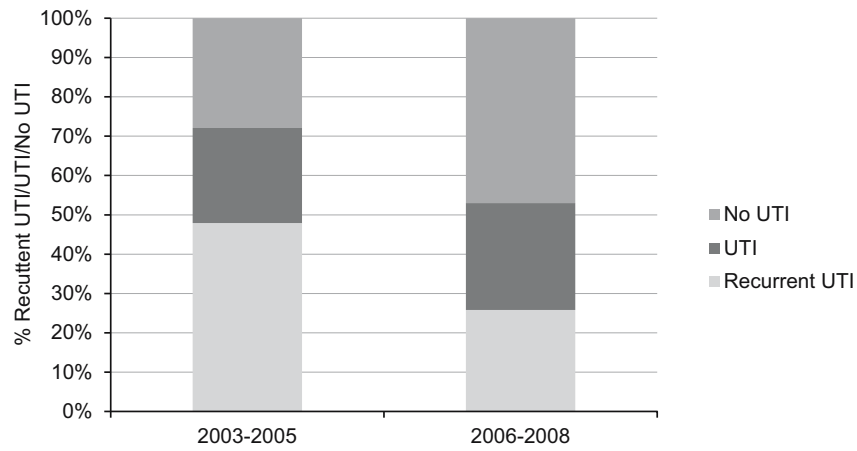

Fig. 3. Graphical representation of the percent of patients with congenital urinary tract malformations who developed urinary tract infections, according to the studied periods

Table II. Distribution of patients who presented one or multiple episodes of urinary tract infections, according to sex and age

\begin{tabular}{|c|c|c|c|c|c|c|c|c|}
\hline \multirow[t]{3}{*}{ Age groups } & \multicolumn{6}{|c|}{ Urinary tract infection } & \multicolumn{2}{|c|}{ Total } \\
\hline & \multicolumn{2}{|c|}{ Recurrent UTI } & \multicolumn{2}{|c|}{ UTI } & \multicolumn{2}{|c|}{ No UTI } & \multirow[b]{2}{*}{ Male } & \multirow[b]{2}{*}{ Female } \\
\hline & Male & Female & Male & Female & Male & Female & & \\
\hline Newborn & 5 & 2 & 10 & 6 & 33 & 16 & 48 & 24 \\
\hline Infant & 14 & 11 & 19 & 8 & 7 & 6 & 40 & 25 \\
\hline $1-6$ years & 19 & 54 & 16 & 23 & 19 & 17 & 54 & 94 \\
\hline $6-12$ years & 11 & 34 & 6 & 13 & 17 & 24 & 34 & 71 \\
\hline $12-18$ years & 1 & 8 & 3 & 7 & 13 & 10 & 17 & 25 \\
\hline Total & 50 & 109 & 54 & 57 & 89 & 73 & 193 & 239 \\
\hline
\end{tabular}


the increased incidence of these infections in patients with malformation background.

Establishing the diagnosis of urinary system congenital malformation in case of 41 patients before the first episode of urinary tract infection can be considered a success.

\section{Discussions}

Urinary infection is always associated with poor prognosis for patients with congenital malformations of the urinary tract. Late diagnosis of the disease may result in progressive development of severe and sometimes irreversible lesions of the renal parenchyma, which facilitate the development of chronic pyelonephritis that may lead to chronic renal failure $[1,7,8]$.

Urinary infection in toddlers has unspecific symptoms, and it is difficult to recognize. Sometimes it can lead to diagnostic errors, when the clinical symptoms are frequently thought to be signs of upper respiratory infections and treated empirically.

In absence of a pre- and postnatal screening program for urinary tract malformations, the occurrence of the urinary tract infection - as the first complication - is usually the factor that leads to the diagnosis of the malformation background.

The fact that patients with congenital malformations of the urinary system coming from urban areas have been diagnosed more frequently with urinary tract infections and recurrent urinary tract infections may be explained not by existence of certain environmental contributing factors, but by the capability for a more precise and quicker diagnosis of urinary tract infections in the urban environment, compared to the rural one.

Analyzing the distribution according to sex of patients with renourinary congenital malformations who also had urinary tract infection, we noted a predominance of females. In a certain way, this may also be explained by an overlap of anatomical characteristics of the female urogenital organs (shorter and straighter urethra, as well as close proximity of the urethral opening to the anal region), as a facilitating condition for UTI, besides the existing congenital malformation of the urinary system.

After studying the incidence of urinary tract infection according to sex and age of the patients of the study group, The increased incidence of UTI in male newborns and infants, as well as female children over 1 year is also reported by other studies. According to certain literature data, the frequency of urinary tract infections in newborns is 5 times as high in males as in females $[9,10]$.

Our study suggests that vesico-ureteral reflux and obstructive lesions of the urinary tract are most frequently associated with urinary infections. Vesico-ureteral reflux contributes to the development of urinary tract infections, as urine regurgitation from the bladder to the ureters and kidneys facilitates the migration of bacteria. Obstructive uropathies contribute to the development of urinary tract infections due to urinary stasis, which in turn is a good environment for bacterial growth $[5,11,12]$.

\section{Conclusions}

Urinary tract infections are the main complication of urinary system congenital malformations. After one year of age and in the presence of a urinary system malformation background, urinary infections are more common in female patients than in males.

As there are no pre- and neonatal screening programs in place, urinary system malformations are commonly diagnosed after the first urinary tract infection episode.

Considering that the first renal scars may appear as early as the first pyelonephritis episodes, urinary tract infections deteriorate the prognosis of patients with congenital renourinary malformations.

In order to improve the prognosis of these patients, congenital malformations of the urinary system need to be diagnosed early, before the development of complications, through screening programs.

\section{References}

1. Bernic J. Infecțiile de tract urinar în uropatiile malformative la copil. Aspecte clinico-paraclinice și medico-chirurgicale. Teza de doctorat, Universitatea de Stat de Medicină și Farmacie "Nicolae Tentemițanu", Chișinău, 2008;19-161.

2. Daescu C, Maris I, Sabau I et al. Therapy of urinary tract infections associated with renourinary malformations in children. Timișoara Medical Journal. 2008;58(suppl. 2):147-153.

3. Joo HL, Hyung SC, Jeong K, et al. Nonrefluxing Neonatal Hydronephrosis and the Risk of Urinary Tract Infection. The Journal of Urology. 2008;179(4): 1524-1528.

4. Muntean I. Cercetări asupra prevlenței factorilor favorizanți în infecția tractului urinar la copil. Teza de doctorat, UMF Tîrgu Mureș, 2002;65-143.

5. Bâscă I. Refluxul vezico-ureteral la copil. Editura Științifică București, 1998;55-78, 103-146

6. Kusztos I, Kiss E. Aspecte clinice ale malformațiilor renourinare la copil. Prahova Pediatric News. 1999;2(2):34-37.

7. Coelho GM, Bouzada MC, Lemos GS, et al. Risk factors for urinary tract infection in children with prenatal renal pelvic dilatation. J Urol. 2008;179(1):284-289.

8. Coman I, Stanca DV, Miu N, et al. Depistarea precoce a malformațiilor genito-urinare la copii. Medic.ro, Urologie. 2006-2007;(30): 87-89.

9. Ramzan M, Bakhsh S, Salam A, et al. Risk factors in urinary tract infection. Gomal Journal of Medical Sciences. 2004;2(1):1-3.

10. Yoon $H$, Jung WL, Seung JL. The risk factors of recurrent urinary tract infection in infants with normal urinary systems. Pediatric Nephrology. 2009;24(2):309-312.

11. Coman I, Stanca D, Miu N, et al. Infecțiile tractului urinar la copil. Abordare nefro-urologică. Ed. Medicală Universitară "Iuliu Hațieganu”, Cluj Napoca, 2003;15-70, 85-109.

12. James L. Infecția de tract urinar la copii. BMJ. 1993;19: 1173-1175. 